\title{
ANALISIS PENGETAHUAN MAHASISWA PGSD UNIVERSITAS RIAU PERIODE 2017- 2019 TERHADAP ALAT MUSIK TRADISIONAL PROVINSI RIAU
}

\author{
Hasbullah $^{1}$, Zufriady $^{2}$, Guslinda $^{3}$ \\ 1,2,3 Universitas Riau, Pekanbaru, Indonesia \\ ${ }^{1}$ hasbullah0285@student.unri.ac.id, ${ }^{2}$ zufriady@lecturer.unri.ac.id, ${ }^{3}$ guslinda@lecturer.unri.ac.id
}

\begin{abstract}
ABSTRAK
Penelitian ini dilatar belakangi oleh, pada era globalisasi sekarang musik semakin lama semakin modern sehingga banyak calon guru sekolah dasar Universitas Riau yang melupakan musik-musik tradisional, sehingga peneliti tertarik untuk menganilisis pengetahuan mahasiswa PGSD Universitas Riau periode 2017-2019 terhadap alat musik tradisional Provinsi Riau. Penelitian ini menggunakan metode kuantitatif deskriptif. Penelitian ini dilakukan pada 358 mahasiswa di PGSD Universitas Riau. Instrument yang digunakan untuk mengumpulkan data adalah tes tertulis yang terdiri dari soal objektif sebanyak 25 butir soal. Hasil penelitian ini menunjukan bahwa mahasiswa yang mendapatkan kategori baik sekali sebanyak $92.73 \%$. Pada kategori baik sebanyak 79.25\%. Pada kategori cukup sebanyak 63.92\%. Pada kategori kurang sebanyak 34.73\%. Umumnya pengetahuan mahasiswa PGSD Universitas Riau berada pada kategori baik dengan nilai rata-rata 72.93 .
\end{abstract}

Kata Kunci: analisis pengetahuan, terhadap alat musik tradisional

\section{ANALYZING THE STUDENTS' KNOWLEDGE ABOUT TRADITIONAL MUSIC TOOLS IN RIAU PROVINCE AT PGSD STUDY PROGRAM OF UNIVERSITAS RIAU DURING THE PERIOD OF 2017-2019}

\begin{abstract}
This research was motivated by the fact that in the era of globalization, music is increasingly modern, so that many prospective primary school teachers from Universitas Riau forget about the traditional music. Thus, the researchers were interested in analyzing the students' knowledge about the traditional musical instruments of Riau Province at the PGSD study program Universitas Riau during the period of 2017-2019. This research used descriptive quantitative method. This research was conducted on 358 students at PGSD study program Universitas Riau.. The instrument used to collect the data was a written test consisting of 25 objective questions. The results of this study indicated that students who got very good categories were $92.73 \%$ while those who got a good category was $79.25 \%$. then, the percentage of students who got enough category was $63.92 \%$, and those who got the less category was $34.73 \%$. Generally, the knowledge of PGSD students was in the good category with an average score of 72.93.
\end{abstract}

Keywords: knowledge analysis, traditional music tools

\begin{tabular}{|c|c|c|}
\hline Submitted & Accepted & Published \\
\hline 22 Desember 2020 & 10 Maret 2021 & 24 Januari 2022 \\
\hline
\end{tabular}

\begin{tabular}{|l|l|r|}
\hline Citation & $:$ & $\begin{array}{r}\text { Hasbullah, H., Zufriady, Z., \& Guslinda, G. (2021). Analisis Pengetahuan Mahasiswa Pgsd Universitas Riau Periode } \\
\text { 2017-2019 Terhadap Alat Musik Tradisional Provinsi Riau. Jurnal PAJAR (Pendidikan dan Pengajaran), 6(1), } \\
\end{array}$ \\
\hline
\end{tabular}

\section{PENDAHULUAN}

Indonesia merupakan suatu Negara yang sangat kaya akan keanekaragaman budaya, hal ini dikarenakan Indonesia terdiri dari berbagai suku bangsa yang mana suku bangsa tersebut memiliki perbedaan dan keunikan tersendiri dan hal lain yang memperkaya keanekaragaman dari budaya itu sendiri.

Menurut Koentjaraningrat (2009:150153).Kebudayaan merupakan kompleks keseluruhan dari pengetahuan, keyakinan, kesenian, moral, hukum, adat istiadat dan semua kemampuan dan kebiasaan yang lain yang diperoleh oleh sesorang sebagai anggota masyarakat. Selain itu kebudayaan memiliki beberapa wujud diantanya: a) wujud kebudayaan sebagai ide, gagasan, nilai atau norma. b) Wujud kebudayaan sebagai aktifitas atau pola tindakan manusia dalam masyarakat. c) Wujud kebudayaan sebagai benda-benda hasil karya manusia.Wujud budaya ini memiliki sifat konkrit Karena merupakan benda-benda dari segala hasil ciptaan, 
karya, tindakan, aktifitas atau perbuatan manusia dalam masyarakat.

Alat musik tradisional merupakan alat musik yang hidup dimasyarakat, dipertahankan sebagai sarana hiburan, yang terbagi dalam 3 komponen didalamnya yang berpengaruh yaitu seniman, musik itu sendiri dan masyarakat yang menikmati dan berkembang secara turun-temurun pada suatu daerah yang digunakan untuk mengiringi sebuah musik-musik yang terdapat dikalangan masyarakat. Tradisi merupakan seni yang hidup, tumbuh dan berkembang ditengahtengah masyarakat pendukungnya tanpa diketahui kapan dan siapa pencipta seni tradisi tersebut. Seni tradisi bukanlah sesuatu yang mati, sekalipun bukan pula sesuatu yang dengan mudah dapat dibongkar atau diingkari. Manusia merupakan bagian dari tradisi bahkan seseorang yang menolak tradisi sekalipun sadar atau tidak, mau atau tidak pada akhirnya akan terbawa mengikuti perkembangan tradisi. Purba (2007:2).

Salah satu seni tradisi yang masih hidup dan berkembang ditengah masyarakat adalah alat musik kompang. Alat musik kompang merupakan seni pertunjukan yang bernafaskan islam, yang ditampilkan dalam upacara perkawinan, khitanan, muharram, aqiqah, dan sebagainya. Selain itu, alat musik kompang juga dijadikan sebagai seni pertunjukan hiburan masyarakat sebgaimana yang di ungkap Soedarsono (1998).

Jenis-jenis alat musik tradisional Provinsi Riau antara lain, Akordeon, Gambus, kompang, marwas, Nafiri, rebana ubi, biola, tetawak, gedang nobat, Gedombak, Camar, Talempong atau calempong, Genggong, bebano, gendang silat.

Globalisasi budaya yang begitu pesat harus diantisipasi dengan memperkuat kebudayaan nasional, jangan sampai kebudayaan nasional hilang, oleh karena itu mengapa pentingnya menanamkan cinta alat musik tradisional, karena merekalah nantinya sebagai generasi yang akan mempertahankan dan memperjuangkan alat musik tradisional Indonesia khususnya di Provinsi Riau. Oleh Karena itu pada era globalisasi sekarang musik semakin lama semakin modern sehingga banyak calon guru sekolah dasar Universitas Riau yang melupakan musik-musik tradisional, sehingga peneliti tertarik untuk menganilisis pengetahuan mahasiswa PGSD Universitas Riau terhadap alat musik tradisional.

\section{METODE PENELITIAN}

Penelitian ini dilakukan di PGSD Universitas Riau. Pelaksanaan penelitian ini dilakukan pada bulan September pada Semester Ganjil tahun 2020/2021. Subjek pada penelitian ini adalah mahasiswa periode 2017-2019 PGSD Universitas Riau, dengan jumlah 358 mahasiswa. Metode yang digunakan pada penelitian ini yaitu metode deskriptif dengan jenis penelitian berupa penelitian kuantitatif. Langkah pertama yang dilakukan peneliti adalah menyiapkan instrumen penelitian berupa 25 butir soal objektif terhadap alat musik tradisional Provinsi Riau. Soal tersebut selanjutnya didiskusikan dengan ahli.

Teknik analisis data yang digunakan dalam penelitian ini adalah teknik tes tertulis yaitu pengetahuan mahasiswa terhadap alat musik tradisional Provinsi Riau. Data yang digunakan pada penelitian ini adalah data kuantitatif, sehingga dalam mengolah data menggunakan analisis data kuantitatif. Data diperoleh melalui hasil tes pengetahuan terhadap alat musik tradisional Provinsi Riau. Penskoran yang digunakan yaitu apabila jawaban benar diberi skor 1 dan jawaban salah diberi skor 0 . Skor yang telah diperoleh dari hasil tes kemudian dikonversi menjadi nilai dengan rentang 0-100.

Seluruh data hasil tes dihitung secara statistika deskriptif, selanjutnya dianalisis secara deskriptif, dan diambil kesimpulannya. Data tersebut dikelompokkan berdasarkan kategorikategori berikut 
Tabel 1. Kategori Penilaian Pengetahuan Alat Musik Tradisional

\begin{tabular}{cc}
\hline Presentase Keberhasilan & Kategori \\
\hline $80-100$ & Baik sekali \\
$70-79$ & Baik \\
$60-69$ & Cukup \\
$50-59$ & Kurang \\
$0-49$ & Kurang sekali \\
\hline
\end{tabular}

(Depdiknas dalam Pebriana, $2011: 22$ )

Setelah masing-masing mahasiswa dikategorikan menurut pengetahuan terhadap alat musik tradisional, kemudian peneliti tabel distribusi frekuensi agar data yang telah dikumpulkan dalam jumlah banyak dapat disajikan

\section{HASIL DAN PEMBAHASAN}

Hasil Penelitian

1. Pengetahuan Mahasiswa Terhadap

Alat Musik Tradisional Provinsi Riau

Pengetahuan mahasiswa terhadap alat musik tradisional Provinsi Riau diperoleh terhadap 5 indikator yaitu,tiup, petik, pukul, tekan dalam bentuk yang jelas dan baik. Selain itu juga untuk menyederhanakan bentuk dan jumlah data sehingga ketika data disajikan akan lebih mudah dipahami.

dan gesek. Analisis berdasarkan penskoran yang kemudian dikonversikan menjadi nilai dan diklasifikasi kedalam 5 kategori yaitu baik sekali, baik, cukup dan kurang. Pengetahuan mahasiswa terhadap alat musik tradisional Provinsi Riau berdasarkan 5 indikator terlihat pada gambar dibawah ini

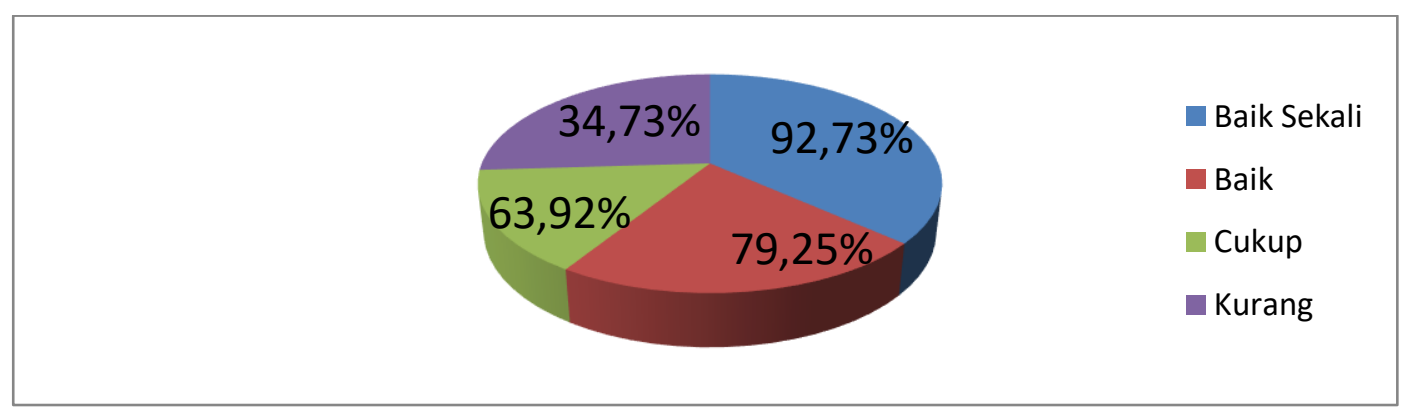

\section{Gambar 1. Pengetahuan Mahasiswa Terhadap Alat Musik Tradisional}

Berdasarkan gambar 1, pengetahuan mahasiswa terhadap alat musik tradisional Provinsi Riau setelah dianalisis dengan menggunakan kategori terlihat bahwa $92.73 \%$ mahasiswa mendapatkan kategori baik sekali. Secara keseluruhan mendapatkan rata-rata 72.93. Berdasarkan rata-rata tersebut, pengetahuan mahasiswa terhadap alat musik tradisional Provinsi Riau termasuk kedalam kategori baik.

\section{Tiup}

pengetahuan mahasiswa dalam menentukan jenis dan cara memainkan alat musik tradisional tiup provinsi riau,mulai dari alat musik nafiri, genggong, ciri-ciri serta bahan dasar pembuatan alat musik tersebut berdasarkan indikator tersebut terlihat pada gambar dibawah ini. 


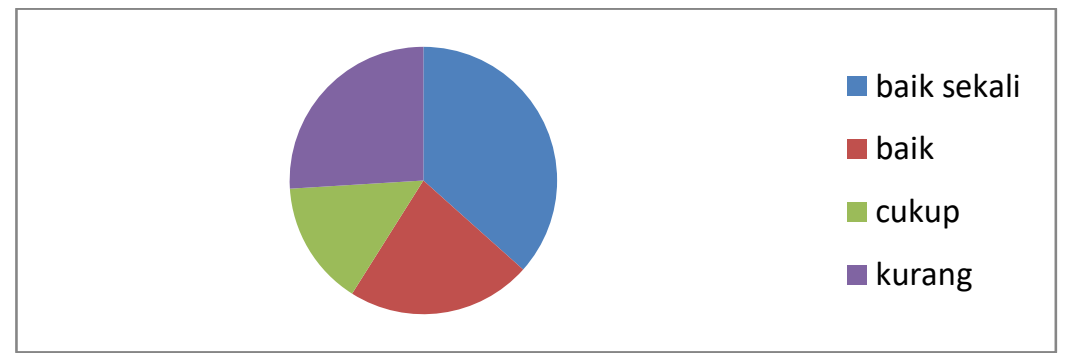

\section{Gambar 2. Pengetahuan Mahasiswa Terhadap Alat Musik Tradisional Tiup}

Berdasarkan gambar 2, mahasiswa yang mendapatkan kategori baik sekali lebih banyak dari pada kategori lainnya dengan nilai rata-rata pada indikator tiup yaitu 69.2388 berdasarkan rata-rata tersebut pengetahuan mahasiswa termasuk dalam kategori cukup.

\section{Petik}

Pengetahuan mahasisw dalam menentukan jenis dan cara memainkan alat musik tradisional petik Provinsi Riau yakni gambus, baik itu jumlah senar, bahan dasar pembuatan gambus serta sumber bunyi yang dihasilkan, berdasarkan indikator tersebut terlihat gambar di bawah ini.

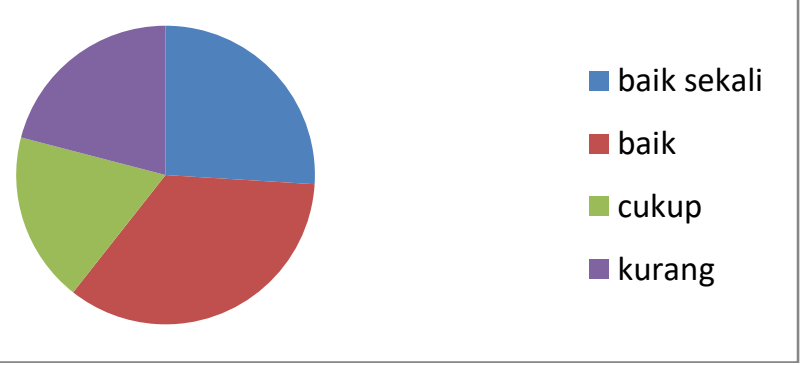

Gambar 3. Pengetahuan Mahasiswa Terhadap Alat Musik Tradisional Petik

Berdasarkan gambar 3, mahasiswa yang mendapatkan kategori baik lebih banyak dari pada kategori lainnya dengan nilai rata-rata pada indikator petik yaitu 73.7 berdasarkan rata-rata tersebut pengetahuan mahasiswa termasuk dalam kategori baik.

\section{Pukul}

Pengetahuan mahasiswa dalam menentukan jenis dan cara memainkan alat musik tradisional pukul Provinsi Riau diantaranya, kompang, rebana ubi, talempong,gendang silat gendang nobat, bebano dan lainya, baik itu bentuk alat musik, bahan dasar pembuatan musik serta cara memainkannya, berdasarkan indikator tersebut terlihat pada gambar di bawah ini.

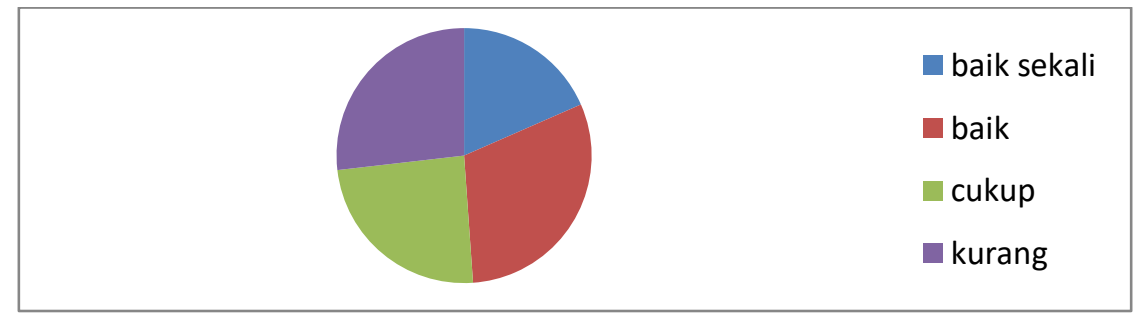

Gambar 4. Pengetahuan Mahasiswa Terhadap Alat Musik Tradisional Pukul 
Berdasarkan gambar 4, mahasiswa yang mendapatkan kategori baik sekali lebih sedikit dari pada kategori lainnya dengan nilai rata-rata pada indikator pukul yaitu 69.18 berdasarkan rata-rata tersebut pengetahuan mahasiswa termasuk dalam kategori cukup.

\section{Tekan}

Pengetahuan mahasiswa dalam menentukan jenis,ciri-ciri dan cara memainkan alat musik tradisional tekan (sentuh) Provinsi Riau, yakni akordeon dan cara memainkannya berdasarkan indikator tersebut terlihat pada gambar dibawah ini.

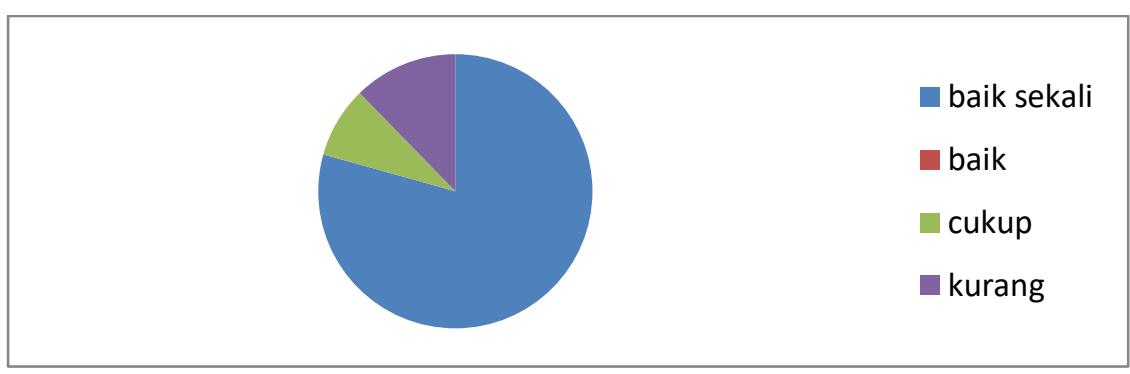

\section{Gambar 5. Pengetahuan Mahasiswa Terhadap Alat Musik Tradisional Tekan}

Berdasarkan gambar 5, mahasiswa yang mendapatkan kategori baik sekali lebih banyak dari pada kategori lainnya dengan nilai rata-rata pada indikator tekan yaitu 87.9 berdasarkan rata-rata tersebut pengetahuan mahasiswa termasuk dalam kategori baik sekali.
6. Gesek

Pengetahuan mahasiswa dalam menentukan jenis,ciri-ciri dan cara memainkan alat musik tradisional gesek Provinsi Riau, yakni biola baik itu jumlah senar keseluruhan bahkan cara memainkannya berdasarkan indikator tersebut terlihat pada gambar di bawah ini.

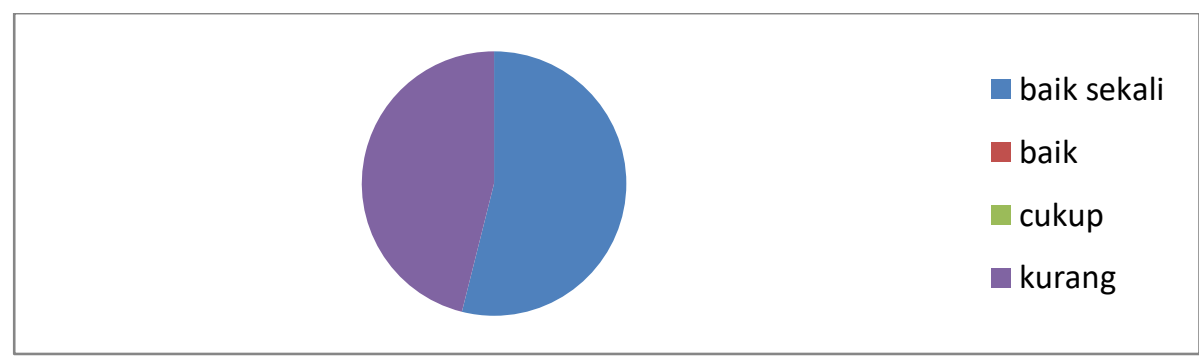

Gambar 6. Pengetahuan Mahasiswa Terhadap Alat Musik Tradisional Gesek

Berdasarkan gambar 6, tidak ada mahasiswa yang mendapatkan kategori baik dan cukup, dengan nilai rata-rata pada indikator gesek yaitu 74.721 berdasarkan rata-rata tersebut pengetahuan mahasiswa termasuk dalam kategori baik sekali.

\section{PEMBAHASAN}

Berdasarkan hasil analisis data menunjukan bahwa pengethauan mahasiswa pgsd terhada alat musik tradisional Provinsi Riau termasuk kedalam kategori "baik" dan nilai ratarata keseluruhan yang diperoleh 72.93. Hasil analisis ke lima indikator juga mendapatkan kategori baik dengan nilai rata-rata paling rendah 
pada indikator ketiga yaitu 69.18 dan nilai rata-rata paling tinggi pada indikator keempat yaitu 87.9.

Pada indikator pertama, yaitu indikator tiup tergolong kedalam kategori cukup dengan nilai rata-rata 69.2388 dalam indikator ini terdapat 8 butir soal dimana pengetahuan mahasiswa diindikator pertama dikatakan cukup, meski ada beberapa mahasiswa yang dari 8 butir soal tidak bisa menjawab benar semuanya, ada yang benar 7 dan 6 bahkan ada juga yang benar 2 atau 3, banyak juga yang tidak tahu alat musik nafiri, genggong, ciri-ciri nya atau bahkan cara memainkannya.

Pada indikator ke dua, yaitu indikator petik tergolong kedalam kategori baik dengan rata-rata 73.7 dalam indikator ini terdapat 6 butir soal dimana pengetahauan mahasiswa diindikator kedua dikatakan baik dengan rata-rata lebih tinggi dari indikator pertama dan ketiga, tapi sebagian mahasiswa masih ada yang keliru atau bahkan ragu dengan jawaban mereka sendiri, seperti jumlah keseluruhan senar gambus dan bahan dasar pembuatan alat musik gambus, tapi pada umumnya pengetahuan mereka masuk kedalam kategori baik.

Pada indikator ke tiga, yaitu indikator pukul yang merupakan indikator terendah dari ke lima indikator penelitian yang tergolong kedalam kategori cukup dengan rata-rata 69.18 dalam indikator ini terdapat 6 buti soal dimana mahasiswa kurang teliti dalam menjawab pertanyaan, banyak mahasiswa yang pengetahuannya seputar alat musik pukul seperti, rebana ubi, gedombak dan camar, baik dari bahan dasar pembuatannya dan cara memainkannya, hal ini perlu diperhatikan bahkan biasa jadi mereka tidak tahu sama sekali, yang mana alat musik tersebut terdengar asing.

Pada indikator ke empat, yaitu indikator tekan (sentuh) yang merupakan indikator tertinggi dari ke lima indikator penelitian yang tergolong kedalam kategori baik sekali dengan rata-rata 87.9 indikator ke emapat merupakan indikator tertinggi dari lima indikator, dalam indikator ini terdapat 3 butir soal dimana yang berkaitan dengan alat musik akordeaon baik itu jenis, ciri-ciri atau cara memainkannya.

Pada indikator kelima, yaitu indikator gesek tergolong kedalam kategori baik dengan rata-rata 74.721 dalam indikator ini terdapat 2 butir soal dimana yang berkaitan dengan alat musik biola baik itu bahan, cara memainkannya dan jumlah senar pada biola, disini terlihat baik tapi masih banyak diantara mahasiswa yang tidak tahu jumlah keseluruhan senar pada alat musik gambus.

Pengetahuan mahasiswa PGSD periode 2017-2019 dari data keseluruhan kelima indikator termasuk kedalam kategori baik, akan tetapi dalam hasil penelitian ini ada beberapa mahasiswa yang tidak tahu tentang alat musik seperti nafiri, gedombak, rebana ubi, genggong yang terdengar asing bagi mereka atau bahkan mereka tidak pernah mendengar sebelumnya. Salah satu faktornya ialah rasa keinginan tahuan mereka kurang, kurangnya membaca dan mempelajari alat musik tradisional Riau.

\section{SIMPULAN DAN REKOMENDASI}

Berdasarkan hasil penelitian yang telah dilakukan oleh peneliti, dapat disimpulkan bahwa pengetahuan mahasiswa PGSD Universitas Riau periode 2017-2019 terhadap alat musik tradisional Provinsi Riau dalam sejauh mana pengetahuan mahasiswa PGSD terhadap alat musik tradisional Provinsi Riau. Berdasarkan hasil analisis data secara keseluruhan menunjukan bahwa pengethauan mahasiswa pgsd terhadap alat musik tradisional Provinsi Riau termasuk kedalam kategori "baik" dan nilai rata-rata keseluruhan yang diperoleh 72.93. 93 mahasiswa dengan nilai rata-rata 92.73 tergolong baik sekali, ada 150 mahasiswa dengan nilai rata-rata 79.75 tergolong baik, ada 55 mahasiswa dengan nilai rata-rata 63.92 tergolong cukup, dan 60 mahasiswa dengan nilai rata-rata 34.73 tergolong kurang. pengetahuan mahasiswa ini diperoleh dari hasil tes yang berupa tes soal objektif yang terdiri dari lima indikator seni musik tradisional.

Namun, jika dilihat per indikator maka nilai kemampuan mahasiswa dalam sejauh mana pengetahuan mahasiswa PGSD Universitas Riau periode 2017-2019 terhadap alat musik tradisional Provinsi Riau berdasarkan indikator tiup memperoleh nilai keseluruhan rata-rata 69.2388 dengan kategori cukup, indikator petik memperoleh nilai keseluruhan rata-rata 73.7 dengan kategori baik, indikator pukul memperoleh nilai keseluruhan rata-rata 69.18 dengan kategori cukup, indikator tekan atau sentuh memperoleh nilai keseluruhan rata-rata 87.9 dengan kategori 
baik sekali, dan indikator gesek memperoleh nilai keseluruhan rata-rata 74.721 dengan kategori baik.

Berdasarkan hasil penelitian maka peneliti mengajukan saran kepada pihak yang terkait dengan penelitian ini, antara lain:

1. Mahasiswa agar dapat lebih meningkatkan lagi pengetahuan dalam musik tradisional pukul dan tiup terkait jenis alat musik itu sendiri seperti rebana ubi,gengong, camar, dan lain lain, bisa dengan membaca,internet ataupun dari sumbernya langsung.

2. Mahasiswa hendaknya dapat membuat perubahan pada perkembangan zaman saat ini, dengan tujuan melestarikan membudayakan alat musik tradisional dikalangan masyarakat yang membuat kehadiran alat musik tradisional itu sendiri tidak punah, atau terlupakan oleh generasi ke generasi.

3. Bagi peneliti lanjutan diharapkan melakukan penelitian pengetahuan mahasiswa pgsd terhadap seni tradisional secara umum dan diharapkan mampu menjadi referensi sebagai data awal dalam mengambil langkah untuk melakukan penelitian yang lebih dalam lagi mengenai pengetahuan mahasiswa terhadap seni musik tradisional.

\section{DAFTAR PUSTAKA}

Agus, M. (2017). Kesenian Tradisional Sebagai Sarana Strategi Kebudayaan Teknolohi Komunikasi. Jurnal Nusa, 12(1), 20-40.

Alexander, J. (2013). Modul Statistik Pendidikan. Pekanbaru: Fkip Universitas Riau.

Arikunto, S. (2007). Dasar-dasar Evaluasi Pendidikan. Jakarta: Bumi Aksara.

Ali, F., \& Suharto, S. (2017). Bentuk Musik Dan Kesenian Jamjaneng Grup Sekar Arum Di Desa Panjer Kabupaten Kebumen. Jurnal Seni Musik, 6(1), 20-35.

Galuh, P. (2013). Bentuk Pertunjukan Dan Nilai Estetis Kesenian Tradisional Terbang Kencer Baitussolikhin Di Desa Bumijawa Kecamatan Bumijawa Kabupaten Tegal. Artikel ISSN 2301-4091 Universitas Negeri Semarang.

Karsono. (2016). Penerapan Model Quantum Learning Dalam Pembelajaran Seni Musik di Sekolah Dasar. Mimbar Sekolah Dasar, $3(2), 50-65$.
Manggih, I. M. (2014). Bentuk Dan Fungsi Kesenian Tong-Tong Prek Desa Jatirejo Kecamatan Ampelgading Kabupaten Pemalang. Jurnal Seni Musik, 3(2), 60-75.

Mareza, L. (2017). Pendidikan Seni Budaya Dan Prakarya (SBdP) Sebagai Strategi Intervensi Umum Bagi Anak Berkebutuhan Khusus. Scholaria, 7(1), 90-110.

Ridwan, S. (2016). Pembelajaran Seni Musik Tematik Sebagai Implementasi Kurikulum 2013. Ritme, 2(2), 95-130.

Ratna, W. D. (2011). Teori-Teori Belajar Dan Pembelajaran. Jakarta: Erlangga.

Ryan, P., \& Endang, D. (2016). Pergeseran Nilai Budaya Pada Suku Bonai Sebagai Civic Culture. Humanika, 23(1), 130-145.

Sugiyono. (2017). Metode penelitian pendidikan pendekatan kuantitatif, kualitatif dan $R \& D$. Bandung: Alfabeta.

Sugiyono. (2014). Cara Mudah Menyunsun: Skripsi, Tesis, Dan Desertasi. Bandung: Alfabeta.

Suardi, S. M. (2018). Belajar Dan Pembelajaran. Yogyakarta: Penerbit Parama Ilmu.

Yulianti, F., \& Satya, D. (2016). Internalisasi Karakter Individu Melalui Pendidikan Musik Menuju Kerangka Konseptual Sebuah Kualitas Pembelajaran. Jurnal Pendidikan dan Kajian Seni, 1(2), 30-45.

Zufriady. (2018). Ekstra Kurikuler Seni Sekolah Dasar di Pekanbaru. Primary: Jurnal Pendidikan Guru Sekolah Dasar, 7(2), 8595.

Zufriady. (2017). Model Pengembangan Kreatifitas Anak Melalui Pembelajaran Seni Budaya Berbasis Musik Riau Bagi Siswa Sekolah Dasar Kelas Atas. Primary: Jurnal Pendidikan Guru Sekolah Dasar, 6(1), 110-125. 